\title{
Blood to Plasma Ratio, Short-Term Stability and Plasma Protein Binding of Casiopeína IIgly, a Copper (II) Based Compound with Antineoplastic Activity
}

\author{
Roberto Carlos Cañas-Alonso, ${ }^{1}$ Inés Fuentes-Noriega, ${ }^{1}$ and Lena Ruiz-Azuara ${ }^{2 *}$ \\ ${ }^{1}$ Departamento de Farmacia, Biofarmacia, Facultad de Química, Universidad Nacional Autónoma de México, Av. Universidad \\ 3000, Ciudad Universitaria 04510, México D.F., México. \\ 2 Departamento de Química Inorgánica Nuclear, Laboratorio de Química Inorgánica Medicinal, Facultad de Química, \\ Universidad Nacional Autónoma de México, Av. Universidad 3000, Ciudad Universitaria 04510, México D.F., México. \\ ruizazuara@gmail.com
}

Received July 1, 2013; Acepted July 22, 2013.

\begin{abstract}
Casiopeína IIgly is a mixed chelate coordination compound with copper (II) core that has shown important antineoplastic activity, even in some resistant cellular lines to Cisplatin. In this work, preclinical studies as blood to plasma ratio, plasma protein binding, short-term stability in blood and pharmacokinetics of this coordination complex are reported. The results indicate that Casiopeína IIgly is stable in blood at least for 6 hours at $37^{\circ} \mathrm{C}$. Also, this compound exhibits an important accumulation in whole blood rather than plasma fluid, a high plasma protein binding ( $>90 \%)$ as well as short half-life (47 min).

Keywords: Casiopeínas, copper compounds, pharmacokinetics, blood to plasma ratio.
\end{abstract}

\section{Introduction}

In recent years bioinorganic chemistry has had an important development especially in relation to medicinal chemistry [1]. In medicinal inorganic chemistry area, many efforts have been done in the development of metal based-drugs for the treatment of several diseases considered as public health problems such as AIDS [2], cancer [3], Alzheimer [4], tropical neglected diseases (Chagas, leishmaniasis, malaria, sleeping sickness, amoebiasis) [5] and bacterial diseases such as tuberculosis [6]. All of them have to fulfill several requirements, as diminishing the toxicity as possible, increase the activity compared with known compounds and reduce the production costs.

Many transition elements, principally of the second and third row, have been used in the production of these drugs. However, recent investigations in this area are focuses on metal-based compounds of essential ions. Copper is an essential trace element important for the function of several enzymes involved in energy metabolism, respiration and DNA synthesis on the cell [7]. The major functions of biological-active copper compounds involve redox reactions in which copper react directly with molecular oxygen or hydrogen peroxide to produce free radicals (ROS) [8], displace other metal ions, participate in lipid peroxidation and directly cleavage of DNA and RNA [9].

All these properties were taken on account in the design of copper (II) coordination compounds patented $[10,11]$ and register under the name Casiopeínas ${ }^{\circledR}[12]$, the general formula
Resumen. La Casiopeína IIgly es un compuesto de coordinación con centro de cobre (II) que ha demostrado tener importante actividad antineoplásica, incluso en líneas celulares resistentes al fármaco Cisplatino. En el presente trabajo se reportan algunos estudios preclínicos realizados a este compuesto como son la relación sangre total/plasma, la unión a proteínas plasmáticas, la estabilidad en sangre a corto plazo y la farmacocinética. Los resultados indican que la Casiopeína IIgly es estable a $37^{\circ} \mathrm{C}$ en sangre al menos por 6 horas. Por otra parte, este compuesto demuestra tener una importante acumulación en sangre total en comparación al plasma, una alta unión a proteínas plasmáticas $(>90 \%)$ así como un corto tiempo de vida media (47 min).

Palabras Clave: Casiopeínas, Compuestos de cobre, farmacocinética, relación sangre total plasma.

are $[\mathrm{Cu}(\mathrm{N}-\mathrm{N})(\mathrm{N}-\mathrm{O})] \mathrm{NO}_{3}$ and $[\mathrm{Cu}(\mathrm{N}-\mathrm{N})(\mathrm{O}-\mathrm{O})] \mathrm{NO}_{3}$ where $\mathrm{N}-$ $\mathrm{N}=$ non substituted and substituted 2,2'-bipyridine or 1,10 phenanthroline, $\mathrm{N}-\mathrm{O}=\alpha$-aminoacidate or peptides and $\mathrm{O}-\mathrm{O}$ $=$ acetylacetonate or salicylaldehydate. Due to its interesting antineoplastic activity, two compounds of this family named Casiopeína IIIia (CasIIIia) and Casiopeína IIgly (CasIIgly) have been investigated in the clinical and preclinical field, respectively [13].

Casiopeína IIgly [Cu(4,7-dimethyl-1,10-phenanthroline)(g lycinato) $\mathrm{NO}_{3}$ has been evaluated in vitro and in vivo showing cytotoxic, genotoxic and antineoplastic activity [14]. Although the action mechanism is still not completely elucidated, there is evidence that supports the idea that this compound is able to inhibit cell proliferation and produce cell dose-dependent death by apoptosis through dependent and independent caspase activation mechanisms [15]. Observed apoptosis might be the result of several processes like ROS generation [16] or mitochondrial toxicity [17-20] that can act alone or in concomitance. In the presence of reducing agents cell growth inhibition and DNA degradation are observed simultaneously of ROS generation, suggesting DNA oxidation as one of the main causes of cell death induction [21]. QSAR study [14], of compounds with general formula $[\mathrm{Cu}(\mathrm{N}-\mathrm{N})$ (acetylacetonato) $] \mathrm{NO}_{3}$ and $[\mathrm{Cu}(\mathrm{N}-$ $\mathrm{N}$ )(glycinato) $\mathrm{NO}_{3}$, has shown that the presence of the third aromatic ring increases cytotoxicity in human tumor cells, also the $\mathrm{E}_{1 / 2}$ value (half wave redox-potential pair $\mathrm{Cu}(\mathrm{II}) / \mathrm{Cu}(\mathrm{I})$ ) is indicative of antiproliferative activity. The above results let us suggest the possibility that this compounds interact with DNA 
by intercalation through the planar moiety corresponding to diimine or acetylacetonate. Also, the interaction with DNA has been observed experimentally [22] and theoretical modeling has been performed $[23,24]$. Some toxicological $[25,26]$ and pharmacokinetics studies $[27,28]$ have been published. However, studies on plasma protein binding, stability in fluids and whole blood to plasma ratio have not yet been carried out, which are important to characterize the preclinical profile of this compound. On the other hand, only one method to measurement Casiopeína IIgly by HPLC-MS has been reported [28]. This method uses $\left[\mathrm{M}+\mathrm{Na}^{+}\right]$specie as internal standard and adducts are known to have reproducibility problems. Moreover, the reported recovery is poor (about $60 \%$ ) and the limit of quantification $(0.1 \mu \mathrm{g} / \mathrm{mL})$ is not sensitive enough for the currently pharmacokinetics and biopharmaceutics studies.

The aim of this work was determinate important preclinical studies of Casiopeína Ilgly such as whole blood to plasma ratio, plasma protein binding, short-term stability and pharmacokinetic profile after an IV dose. In addition, we report a new validated method to quantify this compound with copper core through ion-pairing technology that was used for the analyte measurement.

\section{Results and discussion}

\section{Method validation}

In order to validate this analytical method, parameters as selectivity, matrix effect, linearity, limit of quantification, accuracy, precision, recovery and stability were assayed, in accordance with recommendations of the CDER-FDA Guidance [29]. The retention times of Casiopeína IIgly and IS at the final chromatography conditions were 1.2 and 3.8, respectively. The results indicate that $\% \mathrm{CV}$ of matrix factor between lots to be less than $5 \%$, therefore, no significant matrix effect was observed. The calibration curves were linear over the concentration range of $0.025-10 \mu \mathrm{g} / \mathrm{mL}$ with determination coefficient greater than 0.999. The low limit of quantification was $25 \mathrm{ng}$. The mean of extraction recoveries of Casiopeína IIgly was $86 \%(\% \mathrm{CV}=4 \%)$ and the values were consistent throughout the dynamic range. Inter day and intra day precision were less than $6 \%$ and the accuracy was from $99.42 \%$ to $113 \%$. The mean stability values of Casiopeína IIgly during sample handling (Freeze-thaw stability and short term) were all about $97 \%$.

\section{Preclinical studies}

Previously pharmacokinetic assays of Casiopeína IIgly in rats [27] and dogs [28] both indicate a high elimination rate with low concentrations after an IV administration and intravenous infusion, respectively. This behavior may be consequence of important contribution plasma/blood instability due to possible metabolic degradation or high clearance of the analyte in the tissue of sampling. Therefore, stability assay in beagle, rat and human blood in vitro at $37^{\circ} \mathrm{C}$ were carried out in a period of 6 hours. In all cases, the recoveries found of this coordination complex were within $100.5-88.3 \%$. The results of this determination showed no significant degradation for the three types of whole blood at least 6 hours. Hence, the high rate elimination observed for Casiopeína IIgly in the pharmacokinetics experiments is not consequence of instability in whole blood.

Determinations of blood to plasma ratio for Casiopeína IIgly in samples of human, rat and beagle dog at 0.3 and 1 $\mu \mathrm{g} / \mathrm{mL}$ were determinate quantify the analyte directly in blood as well as in separate plasma and analyzed by HPLC-MS. The time of equilibrium of Casiopeína IIgly between whole blood and plasma was determinate in preliminary experiments and ranged from $15 \mathrm{~min}$ to 2 hours at $37^{\circ} \mathrm{C}$, calculating the rate of migration. The equilibrium was reached within $30 \mathrm{~min}$ therefore; this period of time was used for the formal assay. As reported in table 1, the present experiments showed that Casiopeína IIgly exhibits an important accumulation in whole blood rather than plasma fluid $(\mathrm{Kb} / \mathrm{p}>2.0)$ for dog at $1 \mu \mathrm{g} / \mathrm{mL}$ and human in both concentrations. Furthermore, significant binding to red blood cells $(\mathrm{Ke} / \mathrm{p}>2)$ for human and beagle dog were observed. The values reported in this work indicate some differences in these ratios between species and should be considered in preclinical pharmacokinetic and toxicological assays. According to these data, analysis of whole blood should be preferred over analysis in plasma for Casiopeína IIgly due to higher concentrations in the former tissue with the purpose to increases the sensitivity, and to obtain a lower limit of quantification. Moreover, in the pharmacokinetic field, sampling whole blood rather than plasma could be important to avoid overestimates blood clearance. These findings contributes to understand toxicological evidences previously reported as problems associated to hemolytic anemia and reduced red blood cells counts after an IV administration of Casiopeína IIgly in rats [30]. The bound with red blood cells (RBCs) of

Table 1. Results of blood to plasma ratio $(\mathrm{Kb} / \mathrm{p})$ and red blood cells to plasma ratio $(\mathrm{Ke} / \mathrm{p})$ coefficients of Casiopeína IIgly from three different sources of blood $(n=6)$.

\begin{tabular}{lcccccc}
\hline & \multicolumn{4}{c}{$0.3 \mu \mathrm{g} / \mathrm{mL}$} & \multicolumn{3}{c}{$1 \mu \mathrm{g} / \mathrm{mL}$} \\
\cline { 2 - 6 } & $\mathrm{Hc}(\%)$ & $\mathrm{Kb} / \mathrm{p}$ & $\mathrm{Ke} / \mathrm{p}$ & $\mathrm{Ke} / \mathrm{p}$ & \\
\hline \multirow{2}{*}{ human } & mean (range) & & & mean (range) & \\
rat & 47 & $2.15(1.84-2.27)$ & $3.54(2.79-4.08)$ & $2.47(2.14-2.75)$ & 4.14 & $(3.43-4.74)$ \\
beagle dog & 37 & $0.98(0.93-1.01)$ & $0.95(0.82-1.03)$ & $1.23(1.17-1.28)$ & 1.61 & $(1.46-1.77)$ \\
\hline
\end{tabular}


this coordination complexes and this exposition probably leads to direct erythrocyte damage.

Plasma protein binding was performed by ultrafiltration at concentrations of 1 and $5 \mu \mathrm{g} / \mathrm{mL}$. These concentrations were selected on the basis of the expected therapeutic range of Casiopeína IIgly, which should be below of the $\mathrm{DL}_{1}(2.5 \mathrm{mg} / \mathrm{kg})$ [25]. The suitability of the micropartition device was assured by a control experiment in which filtrate solutions in water of the coordination complex was compared with original solutions in order to calculate the filter retention. As we can see en table 2, the filter exhibit low retention of analyte at the two concentrations tested. Furthermore, Casiopeína IIgly showed extensive protein binding in rat, dog and human plasma (protein binding rate more than 90\%). These data suggested that Casiopeína IIgly associated or administrated in concomitant with other drugs require possibly adjustment of dose in order to avoid emergency toxicity.

Previously, our group reported pharmacokinetics profiles of Casiopeína IIgly during intravenous infusion (1 hour) at 1.5 and $3 \mathrm{mg} / \mathrm{kg}$ in whole blood of beagle dog. Due to the method sensibility, the elimination phase was not fully characterized. Therefore, the present study was thought to obtain the elimination profile of Casiopeína IIgly after a bolus intravenous administration, using the developed method reported in this work. The time courses of the concentrations of Casiopeína IIgly in whole blood of dogs after intravenous administration of 2 $\mathrm{mg} / \mathrm{kg}$ is shown in figure 2 . The concentrations levels could be detected until the 240 minutes post dosing. According to the pharmacokinetic profile, a one-compartment model, first order process was the best-fit model to describe the elimination rate. As shown in table 3 whereby summarized the relevant pharmacokinetic parameters, the half-life obtained after modeling in this assay was short (47 min). Furthermore, the volume of distribution at steady state in male beagle dog was $253 \mathrm{ml} / \mathrm{kg}$ and indicates that Casiopeína IIgly may be distributed in extra-

Table 2. Plasma protein binding of Casiopeína IIgly in rat, dog and human plasma at 2 concentrations $(n=6)$.

\begin{tabular}{lccc}
\hline & & \multicolumn{2}{c}{$\begin{array}{c}\text { Casiopeína IIgly concentration } \\
(\mu \mathrm{g} / \mathrm{ml})\end{array}$} \\
\cline { 3 - 4 } & & 1 & 5 \\
\hline Rat & Range & $89-94$ & $91-97$ \\
& & $92 \pm 1.9$ & $92 \pm 2.3$ \\
Mean \pm S.D. & & $93-97$ \\
Human & Range & $89-97$ & $95 \pm 1.7$ \\
& Mean \pm S.D. & $92 \pm 3.5$ & $97-100$ \\
Filter retention & Range & $93-99$ & $98 \pm 1.2$ \\
& Mean \pm S.D. & $96 \pm 2.8$ & \multicolumn{2}{c}{$3-11$} \\
& Range & \multicolumn{2}{c}{$6.4 \pm 3.5$} \\
\hline
\end{tabular}

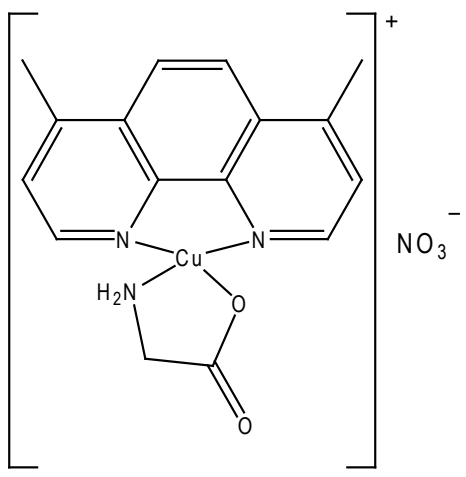

Fig. 1. Chemical structure of Casiopeína IIgly.

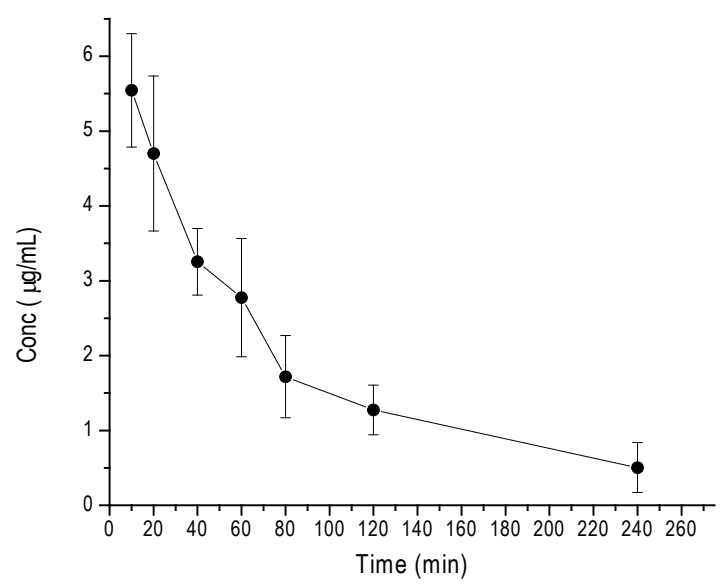

Fig. 2. Blood concentration-time profile of Casiopeína IIgly after intravenous bolus injection in beagle dogs at doses of $2 \mathrm{mg} / \mathrm{kg}$.

vascular compartments. Under the present conditions, we can compare the pharmacokinetics data of the dogs treated by intravenous infusion at doses of 1.5 and $3 \mathrm{mg} / \mathrm{kg}$ to the parameters of the intravenously administrated animals at $2 \mathrm{mg} / \mathrm{kg}$, it can be found that there are differences between its half-life values; 2.45 and 1.90 vs. 0.78 hours, respectively. These data suggesting a non-linear pharmacokinetics and more experiments should be done to get more knowledge about this important parameter that could be affecting a proposed dosage regimen in preclinical and clinical trials.

In conclusion, in this work we reported in further our understanding, relevant biopharmaceutical parameters as blood to plasma ratio, short-term stability and plasma protein binding of Casiopeína IIgly, a copper (II) coordination complex that exhibits antineoplastic activity. Additionally, they provide information that can be useful in the clinical setting.

\section{Experimental}

\section{Chemicals}

Casiopeína IIgly ([Cu(4,7-dimethyl-1,10-phenathroline)(glyc inato) $\left.\mathrm{H}_{2} \mathrm{O}\right] \mathrm{NO}_{3} \cdot \mathrm{H}_{2} \mathrm{O}$ ) was synthesized in the Department of 
Table 3. Blood pharmacokinetics parameters of Casiopeína IIgly in $\operatorname{dogs}(\mathrm{n}=6)$ after intravenous administration at dose of $2 \mathrm{mg} / \mathrm{kg}$.

\begin{tabular}{llll}
\hline Parameter & Units & Value & \% CV \\
\hline K10_HL & min & 47.13 & 12.99 \\
CL & $\mathrm{mL} / \mathrm{min} / \mathrm{kg}$ & 3.73 & 8.98 \\
AUC & $\mathrm{min}^{*} \mu \mathrm{g} / \mathrm{mL}$ & 535.95 & 8.97 \\
AUMC & $\min * \mathrm{~min}^{*} \mu \mathrm{g} / \mathrm{mL}$ & $36,438.13$ & 21.31 \\
MRT & $\min$ & 67.99 & 12.99 \\
Vss & $\mathrm{mL} / \mathrm{kg}$ & 253.7 & 6.6 \\
\hline
\end{tabular}

Inorganic and Nuclear Chemistry (School of Chemistry, Medicinal Inorganic Laboratory, UNAM) following the procedure reported in previous patents $[10,11]$. Prednisone was from USP reference. Heptafluorobutyric acid (HFBA) was purchased from Sigma-Aldrich. Methanol and acetonitrile (both chromatographic grade) from J.T Baker and the deionized water was generated in-house using a Milli-Q system from Millipore (MA. USA).

\section{Sample determination by LC-MS/MS}

A HPLC (Agilent LC, Waldbroon, Germany) coupled to MS detector (Agilent, Ion trap, Palo Alto, CA, USA) equipped with an electrospray ionization source were used to sample analysis. The software using for data processing was LC-MSD Trap Version 3.2 (Agilent-Bruker). Mass spectrometer was operated under positive ion mode and nitrogen was employed as drying gas at $350{ }^{\circ} \mathrm{C}$. The coordination complex and the internal standard (prednisone) was monitored through the time of analysis by selective ion storage (SIS) using the ions $\left[\mathrm{Cu}^{(\mathrm{II})}\left(\mathrm{F}_{7} \mathrm{C}_{3} \mathrm{COO}\right)\right.$ 4,7-dimethyl-1,10-phenanthroline $]^{+}(484 \mathrm{~m} / \mathrm{z})$ and $381 \mathrm{~m} / \mathrm{z}$, respectively. The chromatographic separation was carried out by using a Synergy Polar RP column $(4 \mu \mathrm{m}, 30 \times 2 \mathrm{~mm}, 4 \mu \mathrm{m}$ particle size, Phenomenex) and preceded by a security guard cartridge (Polar RP, 4X3 mm, Phenomenex). The mobile phase consisted in $\mathrm{MeOH} / \mathrm{HFBA} 0.7 \%$ (6:4) and the flow was 0.7 $\mathrm{mL} / \mathrm{min}$ (isocratic).

Sample $(0.5 \mathrm{~mL}$ of whole blood or plasma) was added 100 $\mu \mathrm{L}$ of internal standard (prednisone in methanol, $5 \mu \mathrm{g} / \mathrm{mL}$ ) and $700 \mu \mathrm{L}$ of HFBA (7\% in water), mixed for 45 seconds and centrifuged (1500 rpm, 5 minutes). The mixture was loaded into solid phase extraction cartridge $(33 \mu \mathrm{m}, 60 \mathrm{mg}, 1 \mathrm{cc}$, Phenomenex), washed with $300 \mu \mathrm{L}$ of HFBA (7\% in water) and eluted using $1 \mathrm{~mL}$ of dichloromethane. Further, the sample was concentrated to dryness at $37^{\circ} \mathrm{C}$ under nitrogen. The residue was reconstituted in $100 \mu \mathrm{L}$ of mobile phase and stirred vigorously for 1 minute. Three microliters of mixture were injected and analyzed by LC-MS (ion trap).

\section{Analytical method validation}

The method was validated using five levels for the calibration curve and the concentrations of the points were $0.025,0.5,1$, 5 and $10 \mu \mathrm{g} / \mathrm{mL}$ for whole blood and plasma. The selectivity of the methods was verified by the lack of interfering peaks that co-elute with the analyte or IS, in blank matrices. Matrix effects were evaluated by calculating the ratio of the peak area of Casiopeína IIgly in whole blood or plasma to the peak area in absence of matrix (analyte in solution) from 6 different lots at 3 QC levels (0.1, 3 and $7 \mu \mathrm{g} / \mathrm{mL})$. To assay sensitivity, samples of $25 \mathrm{ng}$ of Casiopeína IIgly in matrix were analyzed through five validation days. Accuracy and precision (intra- e inter- day) for the method were assessed from quality control samples $(0.1,3$ and $7 \mu \mathrm{g} / \mathrm{mL}$ ) per quintuplicated. These values were considered to be acceptable when they were found to be $<15 \%$, except for the LLOQ, where $20 \%$ was allowed. The mean of extraction recoveries of Casiopeína IIgly was obtained by comparing the relative peak area of extracted samples of the coordination complex and blanks spiked post-extraction with Casiopeína IIgy at 3 QC levels $(n=5)$. Freeze and thaw stability was tested a -20 ${ }^{\circ} \mathrm{C}$ using QC samples at 3 concentrations by triplicate. After of the third cycle, the samples were analyzed by HPLC-MS and the concentrations were obtained for interpolating the analytical response in a fresh calibration curve. In order to determinate the short-term stability, spiked blanks with Casiopeína IIgly were prepared at three concentrations $(n=3)$ and they were kept in room temperature for 6 hours.

\section{Short-term stability}

Fresh blood blank of beagle dog, rat or human $(6 \mathrm{~mL})$ were placed into deactivated glass tubes and spiked with Casiopeína IIgly in order to produce a final concentration of 0.3 and 1 $\mu \mathrm{g} / \mathrm{mL}(\mathrm{n}=6)$. Samples were protected from light and stored at $37^{\circ} \mathrm{C}$ during experiment. At times of $0,10,20,40,60 \mathrm{~min}$, 2, 4 and 6 hours, $0.5 \mathrm{~mL}$ of blood was taken and analyzed through HPLC-MS system. To establish stability of Casiopeína IIgly, the results were analyzed through calculation of percent recoveries. Instability was defined to exist when the mean value measured in the particular sample differs from the limits of analytic precision.

\section{Blood to plasma ratio}

Drug free heparinized fresh blood was collected from beagle dog, rat and healthy volunteers (hematocrit value 42, 37 and $47 \%$, respectively). Aliquots $(n=6)$ of Casiopeína IIgly dissolved in methanol were collocated in deactivated glass vials and evaporated under nitrogen at $37{ }^{\circ} \mathrm{C}$. Five milliliters of blood were added to tubes to obtain final concentrations of 0.3 and $1 \mu \mathrm{g} / \mathrm{mL}$ of Casiopeína IIgly. Samples were mixed and incubated for $30 \mathrm{~min}$ at $37^{\circ} \mathrm{C}$. Afterwards, aliquot of blood samples were pipetted into a $1.5 \mathrm{~mL}$ eppendorf tube and centrifuged at $2500 \mathrm{rpm}$ for 5 minutes. The obtained plasma was analyzed by HPLC-MS. In parallel, $0.5 \mathrm{~mL}$ of whole blood was taken from the incubation system, placed in a tube and immediately the sample was frozen and thawed throughout 3 cycles. After, the content of each tube was directly used for sample extraction. Whole blood to plasma partition coefficient of drug $(\mathrm{Kb} / \mathrm{p})$ was calculated from the ratio of concentrations of whole 
blood and plasma and red blood cells (RBCs)-to plasma partition coefficient $(\mathrm{Ke} / \mathrm{p})$ was obtained from the hematocrit value (Hc) and the equation $K_{b / p}=K_{e / p} * H c+(1-\mathrm{Hc})$.

\section{Plasma protein binding assay}

In order to determine plasma protein binding, the ultrafiltration technique was used. Aliquots $(\mathrm{n}=6)$ of Casiopeína IIgly dissolved in water were spiked to the fresh plasma of rat, beagle dog or human to produce a final concentration of 1 and $5 \mu \mathrm{g} / \mathrm{mL}$ and there were mixed by $30 \mathrm{~s}$. After the samples were incubated and protected from light $1 \mathrm{~h}$ at $37^{\circ} \mathrm{C}$. After incubation, $1 \mathrm{~mL}$ of the test solution was placed into ultrafiltration tubes (Centrifree; Amicon, Millipore, Bredford, MA, USA, which had molecular weight cutoff of $30 \mathrm{kDa}$ ) and centrifuged for $30 \mathrm{~min}$ at $4000 \mathrm{rpm}$. Finally, $0.5 \mathrm{~mL}$ of sample ultrafiltrate was analyzed according to the method described in this work. The amount of the test compound was obtained by interpolation in a fresh standard curve. The percentage protein binding was calculated using the formula of protein binding ratio (\%PBR):

$$
\% P B R=\left(1-\frac{\left[\text { Drug }_{\text {ultrafiltrate }}\right]}{\text { Drug }_{\text {total }}}\right) * 100
$$

\section{Pharmacokinetics study in blood of Beagle Dog}

Animal Laboratory Center of Veterinarian Faculty (National Autonomous University of Mexico) supplied six male beagle dogs that weighted between 13.6 and $15.9 \mathrm{Kg}$. Animal experiments were carried out according to our institutional guidelines for the care and the use of laboratory animals and all the study were approved by the Institutional Committee for the care and use of laboratory animals (CICUAL, UNAM). The dogs were housed under controlled environment conditions (temperature rage $20 \pm 3{ }^{\circ} \mathrm{C}$ ) with a commercial food diet and water freely available. Previous the assessment, dogs were fasted with free access to water for 12 hours. On the day of the pharmacokinetic assay, beagle dogs were administered IV at dose of $2 \mathrm{mg} / \mathrm{kg}$. Blood samples $(2 \mathrm{~mL})$ taken from the cephalic vein were collected into heparinized tubes at 10, 20, 40, 60, 80, 120 and 240 minutes and immediately analyzed using the reported analytical method in this work. In order to obtain relevant pharmacokinetic parameters such as half-life time, volume of distribution and clearance, data obtained were processed using WinNonlin software version 5.02 (Pharsight).

\section{Conflict of interest statement}

The authors are affiliated to UNAM. There are no actual or potential conflicts of interest.

\section{Acknowledgments}

This work was supported by CONACYT (RT194130, 179119), PAPIIT217613, ICYT PINVII-32. Authors thank to Maria Ele- na Bravo for Casiopeína IIgly preparation and Marco Leal-García and Luis García-Ortuño for technical assistance in animal handling.

\section{References}

1. Ahmad, S.; Isab, A.; Al-Arfj A. Polyhedron 2006, 25, 16331645

2. Carcelli, M.; Bachi, A.; Pelagatti, P.; Rispoli, G.; Rogolino, D.; Sanchez, T.; Sechi, M.; Neamati, N. J. Inorg. Biochem. 2013, 118, 74-82

3. Cutillas, N.; Yellol, G. S.; de Haro, C.; Vicente, C.; Rodríguez, V. J. Coord. Chem. Rev. 2013 (in press)

4. Madeira, J. M.; Beloukhina, N.; Boudreau, K.; Boettcher, T. A.; Gurley, L.; Walke,r D. G; McNeil, W. S.; Klegeris, A. Eur. J. Pharmacol. 2012, 676, 81-88

5. Navarro, M.; Gabbiani, C.; Messori, L.; Gambino, D. Drug Discov. Today 2010,15, 1070-1078

6. Cuin, A.; Massabni, C.; Pereira, G.; Fujimura, C.; Rogério, F.; Sesti-Costa, R.; Heinrich, T.; Costa-Neto, C. Biomed. Pharmacother. 2011, 65, 334-338

7. Nevit, T.; Öhrvik, H.; Thiele, D. J. Biochim. Biophys. Acta 2012, 1823, 1580-1593

8. Djordjevic, V. B. Int. Rev. Cytol. 2004, 237, 57-89

9. McLachlan, G. A.; Mulle,r J. G.; Rokita, S. E.; Burrows, C. J. Inorg. Chim. Acta 1996, 251, 193-199

10. Ruiz-Azuara, L. US patent 5,576,326, 1996

11. Ruiz-Azuara, L. US patent Re 35,458 1997

12. Ruiz-Azuara, L. México Título de Marca: Casiopeína 1992 Reg. 407543 SECOFI, re. 2002, 2012, 2022

13. Ruiz-Azuara L.; Bravo M. E. Curr. Med. Chem. 2010, 17 (N31), 3606-3615

14. Bravo-Gómez, M. E.; García-Ramos, J. C.; Gracia-Mora, I.; RuizAzuara L. J. Inorg. Biochem. 2009, 103, 299-309

15. Trejo-Solís, C.; Palencia-Hernández, G.; Zúñiga, S.; Rodríguez-Ropon, A.; Osorio-Rico, L.; Sánchez, L.; Gracia-Mora, I.; Márquez-Rosado, L.; Sánchez, A.; Moreno, M. E.; Cruz-Salgado, A.; Bravo-Gómez, M. E.; Ruiz-Ramírez L.; Rodríguez Enríquez, S.; Sotelo J. Neoplasia 2005, 76, 563-574

16. Alemón-Medina, R.; Breña-Valle, M.; Muñóz-Sánchez, J. L.; Gracia-Mora, I.; Ruiz-Azuara, L. Cancer Chemother. Pharmacol. 2007, 60, 219-228

17. Marín-Hernánde,z A.; Gracia-Mora, I.; Ruiz-Ramírez, L.; Moreno-Sánchez, R. Biochem. Pharmacol. 2003, 65, 19791989

18. Kachadourian, R.; Brechbuhl, H. M.; Ruiz-Azura, L.; GraciaMora, I.; Day, B. J. Toxicology 2010, 268, 176-183

19. Gutiérrez, A. G.; Vázquez-Aguirre, A.; García-Ramos, J. C.; Flores-Alamo, M.; Hernández-Lemus, E.; Ruiz-Azuara, L.; Mejía C. J. Inorg. Blochem. 2013, 126, 17-25

20. Valencia-Cruz, A. I.; Uribe-Figueroa, L. I.; Galindo-Murillo, R.; Baca-López, K.; Gutiérrez, A.G.; Vázquez-Aguirre, A.; RuizAzuara, L.; Hernández-Lemus, E.; Mejía, C. Plos. One 2013, 8(1), e54664 (18 p)

21. Rivero-Müller, A.; Plant, N.; Ruiz-Ramírez, L.; de Vizcaya-Ruiz, A.; Dobrota, M. Anticancer Res. 1998, 18, 4936

22. Becco, L.; Rodríguez, A.; Bravo, M. E.; Prieto, M. J.; Ruiz-Azuara, L.; Garat, B.; Moreno, V.; Gambino, D. J. Inorg. Biochem. 2012, $109,49-56$

23. Galindo-Murillo, R.; Hernández-Lima, J.; González-Rendón, M.; Cortés-Guzmán, F.; Ruiz-Azuara, L.; Moreno-Esparza, R. Phys. Chem. Chem. Phys. 2011, 13, 14510-14515

24. García-Ramos, J. C.; Tovar-Tovar, A.; Hernández-Lima, J.; Cortés-Guzmán, F.; Moreno-Esparza, R.; Ruiz-Azuara, L. Polyhedron 2011, 30, 2697-2703 
25. Leal-García, M.; García-Otuño, L.; Ruiz-Azuara, L.; Gracia-Mora, I.; Luna-delVillar, J.; Sumano, H. Basic Clin. Pharmacol. Toxicol. 2007, 101, 151-158

26. Hernández-Esquive,1 L.; Marín-Hernández, A.; Pavón, N.; Carvajal, K.; Moreno-Sánchez, R. Toxicol. Appl. Pharmacol. 2006, 212, 79-88

27. Reyes, L.; Fuentes-Noriega, I.; Ruiz-Ramírez, L.; Macías, L. J.
Chromatogr. B Biomed. Sci. Appl. 2003, 79, 111-116

28. Cañas-Alonso, R. C.; Fuentes-Noriega, I.; Ruiz-Azuara, L. Journal Bioanal. Biomed. 2010, 2, 28-34

29. FDA-CDER. Guidance for Industry. Bioanalytical Method Validation 2001.

30. De Vizcaya-Ruiz, A.; Rivero-Müller, A.; Ruiz-Ramirez, L.; Howarth, J. A.; Dobrota, M. Toxicology 2003, 194, 103-113. 